\title{
Article \\ Dissolution Behavior of Different Inclusions in High Al Steel Reacted with Refining Slags
}

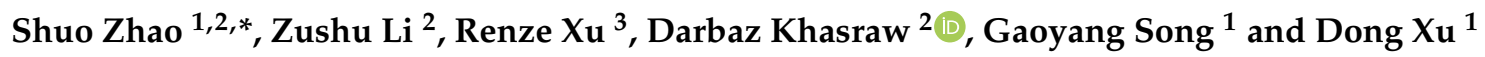 \\ 1 Technology Innovation Center for High Quality Cold Heading Steel of Hebei Province, Department of \\ Materials Science and Engineering, Hebei University of Engineering, Handan 056038, China; \\ sgy_beike@163.com (G.S.); xudong_xyz@163.com (D.X.) \\ 2 Warwick Manufacturing Group, University of Warwick, Coventry CV4 7AL, UK; \\ z.li.19@warwick.ac.uk (Z.L.); D.Khasraw@warwick.ac.uk (D.K.) \\ 3 Department of Metallurgical and Ecological Engineering, University of Science and Technology Beijing, \\ Beijing 100083, China; xurenze2010@163.com \\ * Correspondence: zhaos418@hebeu.edu.cn
}

Citation: Zhao, S.; Li, Z.; Xu, R.; Khasraw, D.; Song, G.; Xu, D. Dissolution Behavior of Different Inclusions in High Al Steel Reacted with Refining Slags. Metals 2021, 11, 1801. https://doi.org/10.3390/ met11111801

Academic Editor: Sergey V. Zherebtsov

Received: 10 September 2021 Accepted: 1 November 2021 Published: 9 November 2021

Publisher's Note: MDPI stays neutral with regard to jurisdictional claims in published maps and institutional affiliations.

Copyright: (c) 2021 by the authors. Licensee MDPI, Basel, Switzerland. This article is an open access article distributed under the terms and conditions of the Creative Commons Attribution (CC BY) license (https:// creativecommons.org/licenses/by/ $4.0 /)$.

\begin{abstract}
Al}_{2} \mathrm{O}_{3}, \mathrm{Al}_{2} \mathrm{O}_{3} \cdot \mathrm{TiN}, \mathrm{Al}_{2} \mathrm{O}_{3} \cdot \mathrm{MgO}$, and $\mathrm{CaO} \cdot 2 \mathrm{Al}_{2} \mathrm{O}_{3}$ are four different types of inclusions in high $\mathrm{Al}$ steels. To improve the steel cleanness level, the effective removal of such inclusions during secondary refining is very important, so these inclusions should be removed effectively via inclusion dissolution in the slag. The dissolution behavior of $\mathrm{Al}_{2} \mathrm{O}_{3}, \mathrm{Al}_{2} \mathrm{O}_{3} \cdot \mathrm{TiN}, \mathrm{Al}_{2} \mathrm{O}_{3} \cdot \mathrm{MgO}$, and $\mathrm{CaO} \cdot 2 \mathrm{Al}_{2} \mathrm{O}_{3}$ in $\mathrm{CaO}-\mathrm{SiO}_{2}-\mathrm{Al}_{2} \mathrm{O}_{3}-\mathrm{MgO}$ slags, as well as the steel-slag reaction, was investigated using laser scanning confocal microscopy (LSCM) and high-temperature furnace experiments, and thermodynamic calculations for the inclusion in steel were carried out by FactSage 7.1. The results showed that $\mathrm{Al}_{2} \mathrm{O}_{3}$. TiN was observed to be completely different from the other oxides. The composite oxides dissolved quickly in the slags, and the dissolution time of the inclusions increased as their melting point increased. $\mathrm{SiO}_{2}$ and $\mathrm{B}_{2} \mathrm{O}_{3}$ in the slag were almost completely reacted with [Al] in steel, so the slags without $\mathrm{SiO}_{2}$ showed a positive effect for avoiding the formation of $\mathrm{Al}_{2} \mathrm{O}_{3}$ system inclusions and promoting inclusions dissolution as compared with $\mathrm{SiO}_{2}$-rich slags. The steel-slag reaction was also found to influence the inclusion types in steel significantly. Because of the rapid absorption of different inclusions in the slag, it was found that the dissolution time of inclusions mainly depends on the diffusion in the molten slag.
\end{abstract}

Keywords: LSCM; high Al steel; inclusions; refining slag; dissolution

\section{Introduction}

High-Al steel usually refers to steel grades with more than $0.7 \%$ aluminum in molten steel. It is difficult to avoid the formation of hard alumina system non-metallic inclusions in today's steelmaking process [1-5]. The quality of high alumina steel is closely related to the characteristics and quantities of non-metallic inclusions. The control of these inclusions is mainly carried out in two steps: changing the morphology and composition of the inclusions, and then removing the inclusions into the slag phase. For the first step, S.P. He and K.W. Zhao found that low melting point $\mathrm{CaO}-\mathrm{Al}_{2} \mathrm{O}_{3}$ inclusions were generated through slag washing with low $\mathrm{SiO}_{2}$ high basicity slag [6,7]. R. Wang reported that the morphology of inclusions in automobile steel can be changed by the interaction between inclusions and refining slag, where $\mathrm{Al}_{2} \mathrm{O}_{3}$ dissolution speed increased with the increase of $\mathrm{CaO} / \mathrm{Al}_{2} \mathrm{O}_{3}$ in top slag [8]. B. J. Monaghan reported that spinel inclusion dissolution can be affected by changing the slag composition, where the rate controlling mechanism for $\mathrm{Al}_{2} \mathrm{O}_{3}$ microparticle dissolution in the liquid oxide compositions was found to be controlled by mass transfer in the liquid oxide [9]. On this basis, further research on the separation of inclusions from molten steel, and the adsorption and dissolution behavior in the slag become a scientific frontier issue. In order to achieve removing inclusions, it is especially important to get through the last step in high-Al steel. 
In recent years, many researchers have focused in-situ observations of different inclusions in steel by means of laser scanning confocal microscopy (LSCM). H. Shibata and H.B. Yin began to focus on single $\mathrm{Al}_{2} \mathrm{O}_{3}$ inclusions in the late 1990s [10,11], and S.K. Michelic discussed the dissolution behavior of titanium oxide and titanium nitride in Ti-microalloying ferritic stainless steels $[12,13]$. The removal dynamic models of single large inclusion were established by W. Liu and M.Z. Mu et al. [14-16]. In reality, the number of large alumina and composite inclusions in Al killed steel is relatively small, but the proportion of small inclusions is higher. There are few in-situ studies on fine composite inclusions such as calcium aluminate, spinel, and alumina-titanium nitride. In addition, it has not been studied for the absorption and dissolution process of fine inclusions in refining slag used for high $\mathrm{Al}$ steel in particular. Based on the previous research results, the corresponding refining slags were selected according to different types of micro-inclusions in this research. Secondly, the dissolution process of the composite inclusions in refining slag and the modification of inclusions in high Al steel after the interaction with top slag were analyzed, the absorption and reaction process of the inclusions was studied finally.

\section{Thermodynamic Calculation}

The reactions of $\mathrm{Al}_{2} \mathrm{O}_{3}, \mathrm{Al}_{2} \mathrm{O}_{3} \cdot \mathrm{TiN}, \mathrm{MgO} \cdot \mathrm{Al}_{2} \mathrm{O}_{3}$, and $\mathrm{CaO} \cdot 2 \mathrm{Al}_{2} \mathrm{O}_{3}$ with different $\mathrm{CaO}-\mathrm{Al}_{2} \mathrm{O}_{3}-\mathrm{SiO}_{2}-\mathrm{MgO}$ refining slags were calculated using FStel and FToxid databases in FactSage 7.1. According to the previous reports [6,7], the $\mathrm{SiO}_{2}$ content in the refining slag suitable for high aluminum steel with $1 \mathrm{wt} \%$ [Al] is generally lower than $5 \mathrm{wt} \%$, so the composition of the refining slag designed in this experiment is shown in Table 1.

Table 1. Compositions of the experimental slag, wt $\%$.

\begin{tabular}{ccccccc}
\hline Type & $\mathbf{C a O}$ & $\mathbf{A l}_{\mathbf{2}} \mathbf{O}_{\mathbf{3}}$ & $\mathbf{M g O}$ & $\mathbf{S i O}_{\mathbf{2}}$ & $\mathbf{B}_{\mathbf{2}} \mathbf{O}_{\mathbf{3}}$ & $\mathrm{CaO}_{\mathbf{A}} \mathbf{A l}_{\mathbf{2}} \mathbf{O}_{\mathbf{3}}$ \\
\hline Slag 1 & 54.1 & 31.9 & 6.00 & 5.00 & 3.00 & 1.7 \\
Slag 2 & 50.2 & 35.8 & 6.00 & 5.00 & 3.00 & 1.4 \\
Slag 3 & 53.1 & 37.9 & 6.00 & - & 3.00 & 1.4 \\
\hline
\end{tabular}

The interaction calculated results between the slag and inclusions at $1550{ }^{\circ} \mathrm{C}$ can be seen in Figures 1-4. This shows the change of different components in slag with various inclusions entering slag. By comparing the reaction results of the four inclusions in three slags, the effect of the inclusion absorption on the slag composition can be controlled, and the following conclusions can be obtained:

1. With the increase of adding the amount of $\mathrm{Al}_{2} \mathrm{O}_{3}$ inclusions, the $\mathrm{Al}_{2} \mathrm{O}_{3}$ content in the three slags increased gradually, with an average increase of about $2 \mathrm{wt} \%$. As the weight of the total slag remained basically unchanged, the other components, $\mathrm{CaO}$, $\mathrm{SiO}_{2}, \mathrm{MgO}$, and $\mathrm{B}_{2} \mathrm{O}_{3}$, in the refining slag showed a decreasing trend, in which the reduction of $\mathrm{CaO}$ was up to $1.58 \%$, with $\mathrm{SiO}_{2}, \mathrm{MgO}$, and $\mathrm{B}_{2} \mathrm{O}_{3}$ reduced below $0.18 \%$.

2. With the increase of $\mathrm{Al}_{2} \mathrm{O}_{3} \cdot \mathrm{TiN}$ inclusions, the $\mathrm{Al}_{2} \mathrm{O}_{3}$ content in the three slags also gradually increased, with an average increase of about $1 \mathrm{wt} \%$. Due to the presence of $\mathrm{TiN}$, new components such as $\mathrm{TiO}_{2}$ and $\mathrm{Ti}_{2} \mathrm{O}_{3}$ were generated in the slag, for which the contents were both less than $1.2 \mathrm{wt} \%$. It is estimated that the following reaction (1) occurred between the inclusion and slag 1 , resulting in the formation of titanium oxides [13]. In addition, new nitrides such as $\mathrm{Ca}_{3} \mathrm{~N}_{2}, \mathrm{Mg}_{3} \mathrm{~N}_{2}, \mathrm{AlN}, \mathrm{Si}_{3} \mathrm{~N}_{4}, \mathrm{BN}$, and $\mathrm{Ti}_{3} \mathrm{~N}_{4}$ were generated, and their contents were very low. Due to the formation of new compounds, the other components, namely $\mathrm{CaO}, \mathrm{SiO}_{2}$, and $\mathrm{B}_{2} \mathrm{O}_{3}$ of the refining slag, showed a decreasing trend. $\mathrm{MgO}$ decreased in both slag 2 and slag 3, but increased slightly in slag 1 . The further reaction between $\mathrm{MgO}$ and alkaline oxides in the slag led to the precipitation of cristobalite and $\mathrm{Ca}_{3} \mathrm{Ti}_{2} \mathrm{O}_{6}$.

$$
\mathrm{x}(\mathrm{TiN})+\frac{\mathrm{y}}{2}\left(\mathrm{SiO}_{2}\right)=\left(\mathrm{Ti}_{\mathrm{x}} \mathrm{O}_{\mathrm{y}}\right)+\frac{\mathrm{y}}{2}[\mathrm{Si}]+\frac{\mathrm{x}}{2}\left\{\mathrm{~N}_{2}\right\}
$$


3. With the increase of $\mathrm{Al}_{2} \mathrm{O}_{3} \cdot \mathrm{MgO}$ inclusions, the $\mathrm{Al}_{2} \mathrm{O}_{3}$ content in the three slags also gradually increased, and the average value improved by about $1 \mathrm{wt} \%$. Due to the absorption effect of the refining slag on the $\mathrm{MgO}$ component, the $\mathrm{MgO}$ content in the slag also increased by $0.65 \%$, and all other components showed a decreasing trend- $\mathrm{CaO}$ was reduced by $1.58 \mathrm{wt} \%$, and $\mathrm{SiO}_{2}$ and $\mathrm{B}_{2} \mathrm{O}_{3}$ were reduced by $0.15 \mathrm{wt}-\%$ and $0.09 \mathrm{wt} \%$ respectively.

4. With the increase of $\mathrm{CaO} \cdot 2 \mathrm{Al}_{2} \mathrm{O}_{3}$ inclusions, the $\mathrm{Al}_{2} \mathrm{O}_{3}$ content also gradually increased in slag 1 and slag 2 , and the increasing value exceeded $1 \mathrm{wt} \%$. Although the other components, namely $\mathrm{CaO}, \mathrm{SiO}_{2}, \mathrm{~B}_{2} \mathrm{O}_{3}$, and $\mathrm{MgO}$, in the slag showed a downward trend, the decrease in the $\mathrm{CaO}$ component was less than $1 \mathrm{wt} \%$, and the downward trend was weakened. This was due to the decomposition reaction of the calcium aluminate inclusions, and the refining slag absorbed the product $\mathrm{CaO}$.
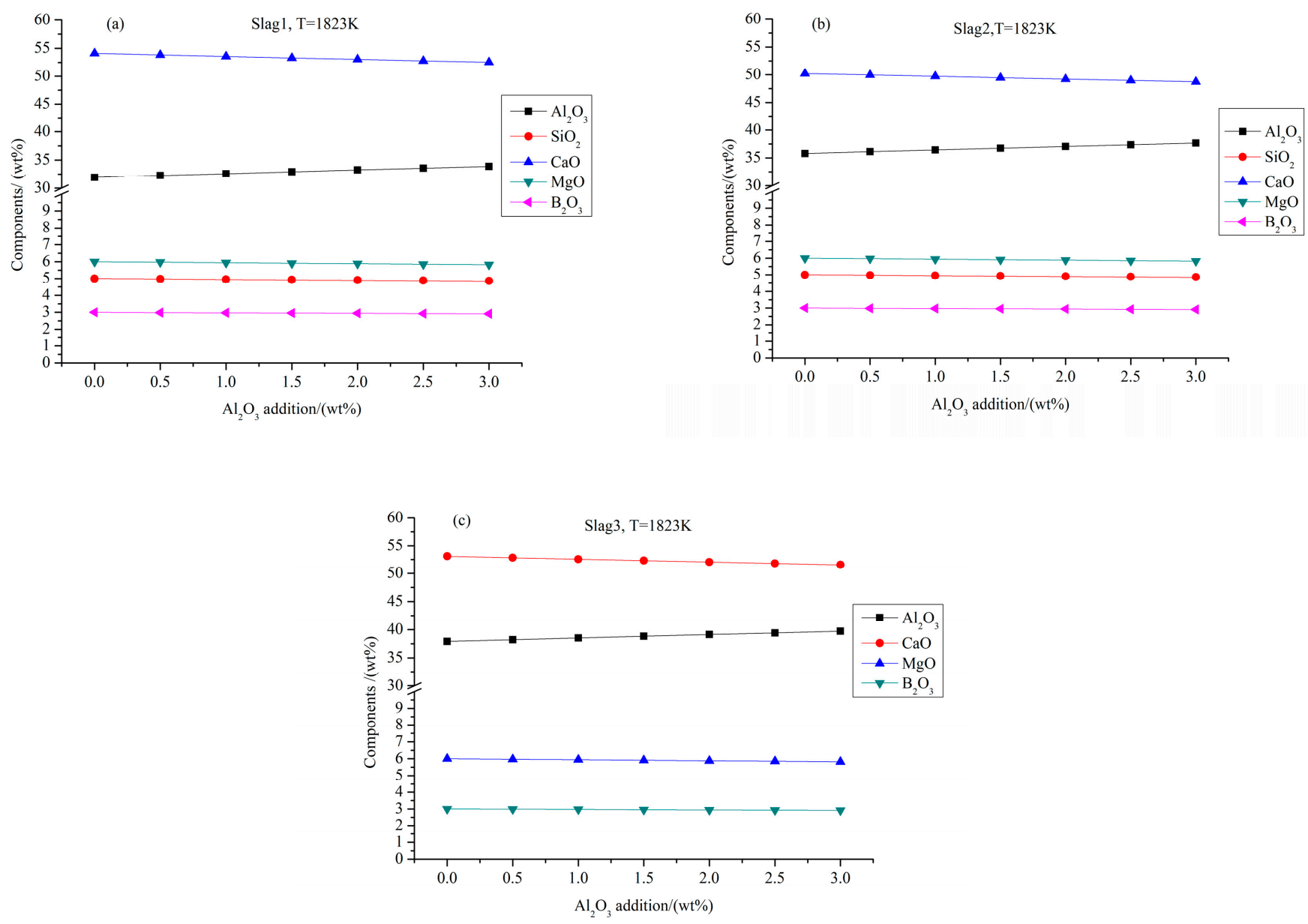

Figure 1. Thermodynamic calculation of the reaction between $\mathrm{Al}_{2} \mathrm{O}_{3}$ and slags with different compositions: (a) slag 1, (b) slag 2, and (c) slag 3 . 

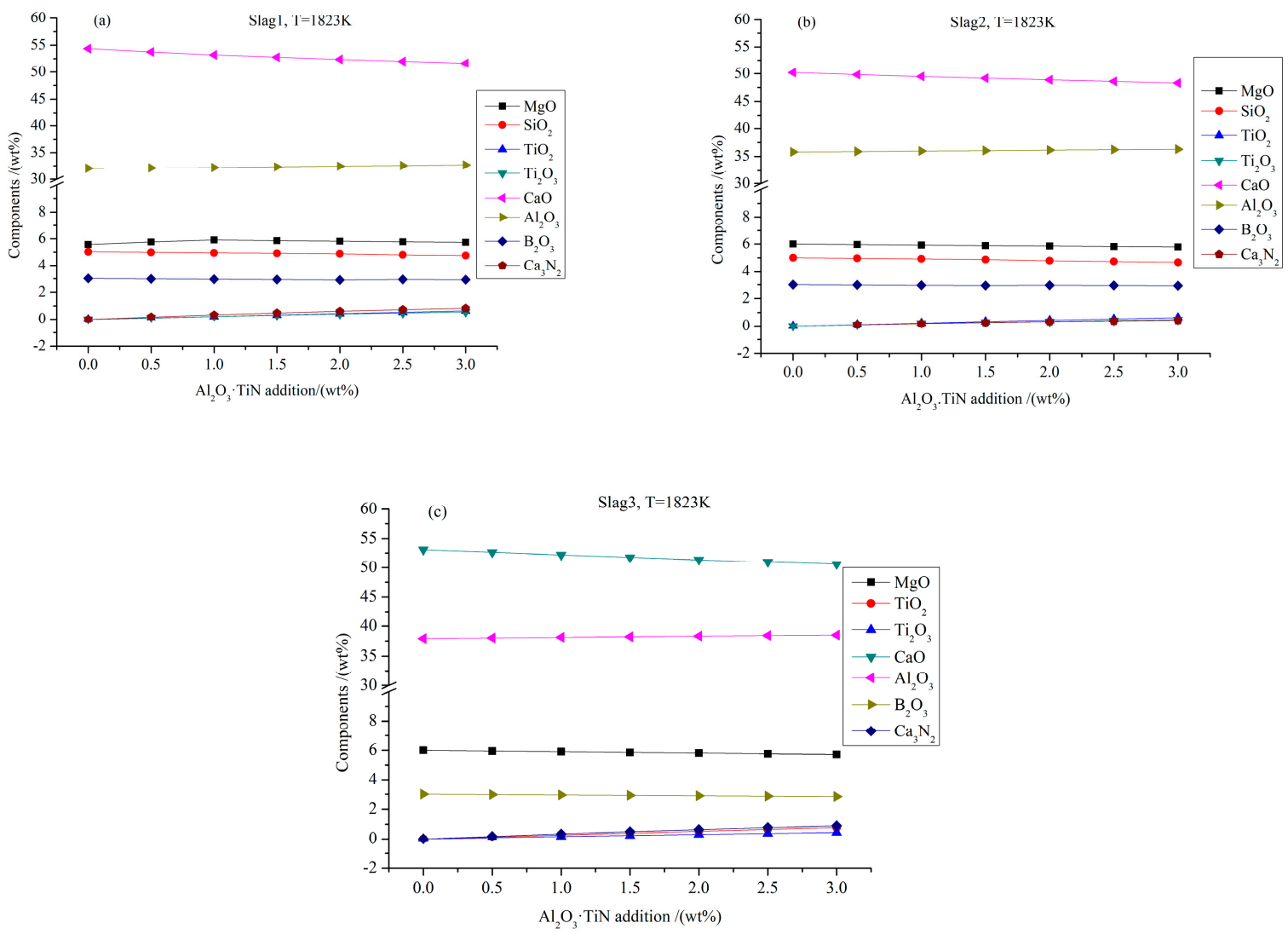

Figure 2. Thermodynamic calculation of the reaction between $\mathrm{Al}_{2} \mathrm{O}_{3} \cdot \mathrm{TiN}$ and slags with different compositions: (a) slag 1, (b) slag 2, and (c) slag 3 .
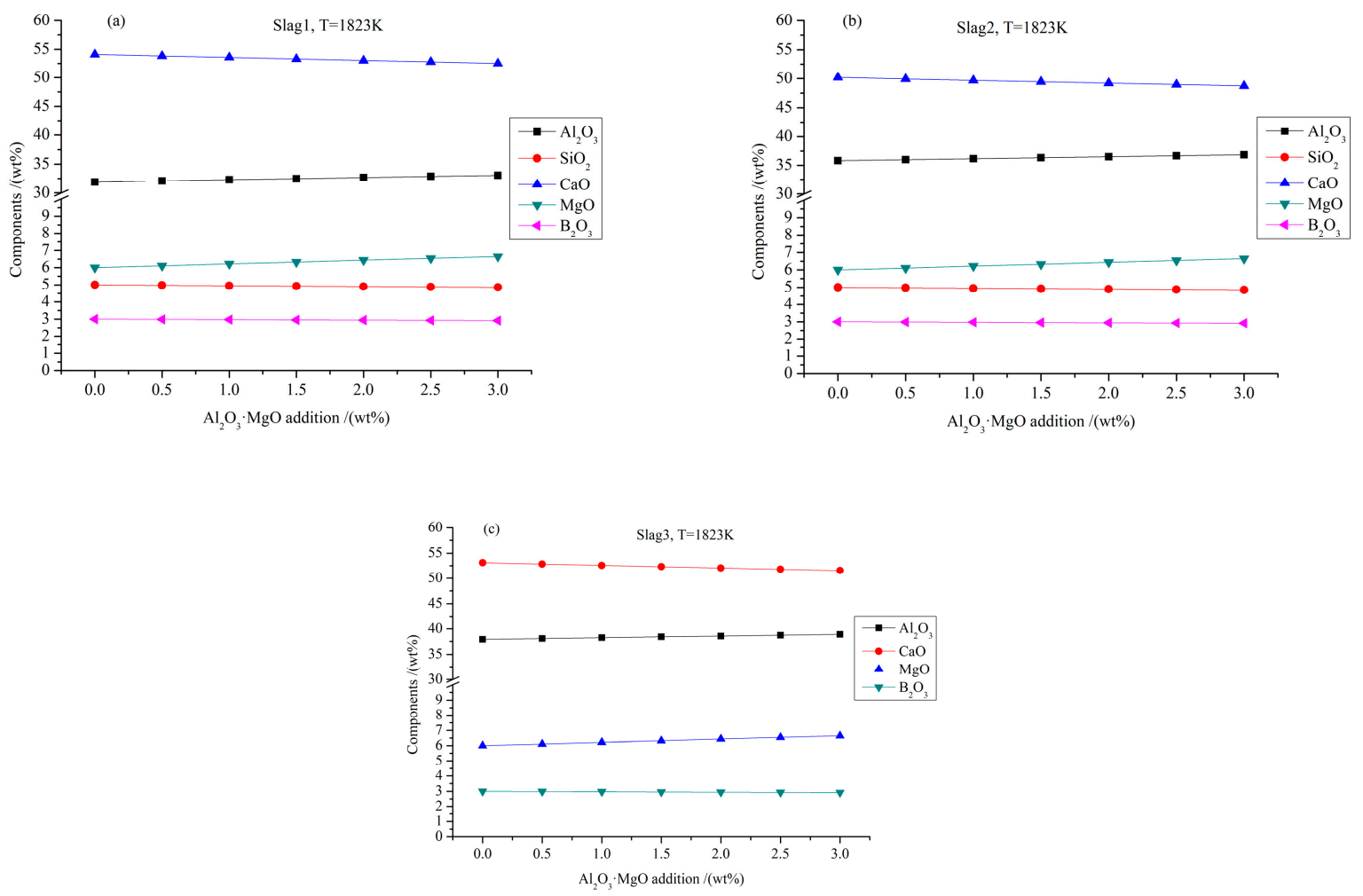

Figure 3. Thermodynamic calculation of the reaction between $\mathrm{MgO} \cdot \mathrm{Al}_{2} \mathrm{O}_{3}$ and slags with different compositions: (a) slag 1, (b) slag 2, and (c) slag 3 . 

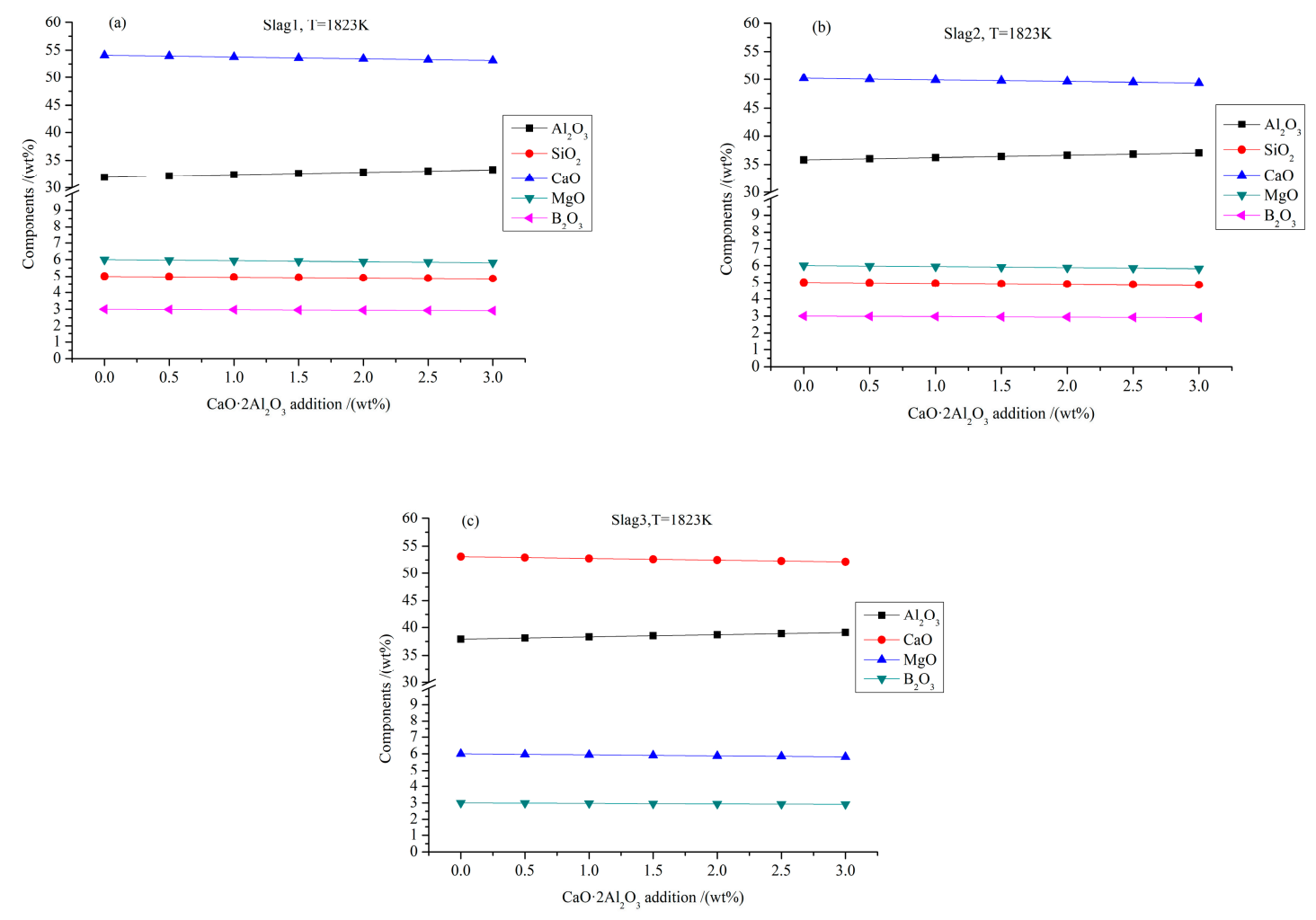

Figure 4. Thermodynamic calculation of the reaction between $\mathrm{CaO} \cdot 2 \mathrm{Al}_{2} \mathrm{O}_{3}$ and slags with different compositions: (a) slag 1 , (b) slag 2, (c) slag 3 .

\section{Experiment Plan}

\subsection{Aggregation Behavior of Inclusions in Steel}

The high aluminum steel was prepared using a vacuum induction furnace in the laboratory. First, the behavior and type of original inclusions in the $15 \mathrm{~mm} \times 15 \mathrm{~mm} \times 15 \mathrm{~mm}$ samples were observed using a scanning electron microscope (SEM) made by Zeiss, Oberkochen, Germany.

The steel sample was placed in the corundum crucible $(5 \mathrm{~mm} \times 4.5 \mathrm{~mm} \times 3.5 \mathrm{~mm})$, heated to $1773 \mathrm{~K}\left(1500{ }^{\circ} \mathrm{C}\right)$ at $1000 \mathrm{~K} / \mathrm{min}$, and then heated to $1873 \mathrm{~K}\left(1600^{\circ} \mathrm{C}\right)$ at $100 \mathrm{~K} / \mathrm{min}$ by LSCM. The corundum gasket was placed under the steel to prevent the steel from sticking to the crucible. After reaching the set temperature, the inclusions began to move from the interior to the surface of molten steel, and then the aggregation behavior of the inclusions was observed. To avoid the liquid steel becoming droplets due to interfacial tension, a certain space should be maintained between the solid sample and crucible.

\subsection{Dissolution Behavior of Inclusions on the Slag Surface}

Based on the $1 \mathrm{wt} \% \mathrm{Al}$ content, the composition of the refining slag $(\mathrm{CaO}, \mathrm{MgO}$, $\mathrm{SiO}_{2}, \mathrm{Al}_{2} \mathrm{O}_{3}$, and $\left.\mathrm{B}_{2} \mathrm{O}_{3}\right)$ and the typical inclusions in molten steel (1) $\mathrm{Al}_{2} \mathrm{O}_{3}$, (2) $\mathrm{Al}_{2} \mathrm{O}_{3} \cdot \mathrm{TiN}$, (3) $\mathrm{Al}_{2} \mathrm{O}_{3} \cdot \mathrm{MgO}$, and (4) $\mathrm{CaO} \cdot 2 \mathrm{Al}_{2} \mathrm{O}_{3}$ ) were determined. The properties of four different inclusions can be seen in Table 2, and $\mathrm{Al}_{2} \mathrm{O}_{3} \cdot \mathrm{TiN}, \mathrm{Al}_{2} \mathrm{O}_{3} \cdot \mathrm{MgO}$, and $\mathrm{CaO} \cdot 2 \mathrm{Al}_{2} \mathrm{O}_{3}$ were prepared using pure compounds. To prepare these composite inclusions, it was necessary to press them into a thin disk in advance, and to sinter them for $24 \mathrm{~h}$ at $1873 \mathrm{~K}\left(1600{ }^{\circ} \mathrm{C}\right)$. The primary sintering product was broken into fine powder for secondary sintering, and the sintering temperature was $1923 \mathrm{~K}\left(1650^{\circ} \mathrm{C}\right)$ and the holding time was $6 \mathrm{~h}$. 
Table 2. Molar mass $(\mathrm{g} / \mathrm{mol})$ and melting points of the inclusions.

\begin{tabular}{cccccc}
\hline Type & $\mathbf{A l}_{\mathbf{2}} \mathbf{O}_{\mathbf{3}}$ & $\mathbf{T i N}$ & $\mathbf{M g O}$ & $\mathbf{C a O}$ & Melting Point, ${ }^{\circ} \mathbf{C}$ \\
\hline Inclusion 1 & 102 & & & & 2054 \\
Inclusion 2 & 102 & 61.9 & & & 2930 \\
Inclusion 3 & 102 & & 40 & & 2250 \\
Inclusion 4 & 102 & & & 28 & 1762 \\
\hline
\end{tabular}

The slag sample was placed into the Pt crucible first, and then the simulated inclusion particles were placed on the slag sample. The slag sample made by pure reagents was premelted, crushed, and dried gradually. Its composition was determined by X-ray fluorescence spectrometer (XRF). The inclusion particles were put into the slag after melting, and the lower melting point slag (inclusion particle) was heated to $1623 \mathrm{~K}\left(1350{ }^{\circ} \mathrm{C}\right)$ at $700 \mathrm{~K} / \mathrm{min}$, then to $1823 \mathrm{~K}\left(1550^{\circ} \mathrm{C}\right)$ at $100 \mathrm{~K} / \mathrm{min}$. The higher melting point slag (inclusion particles) was heated to $1723 \mathrm{~K}\left(1450{ }^{\circ} \mathrm{C}\right)$ at $1000 \mathrm{~K} / \mathrm{min}$, and then to $1823 \mathrm{~K}\left(1550{ }^{\circ} \mathrm{C}\right)$ at $100 \mathrm{~K} / \mathrm{min}$. The heating should be rapid in the early stage to prevent inclusions melting before reaching a predetermined temperature. The thermal cycle curve in LSCM experiments can be seen in Figure 5 .

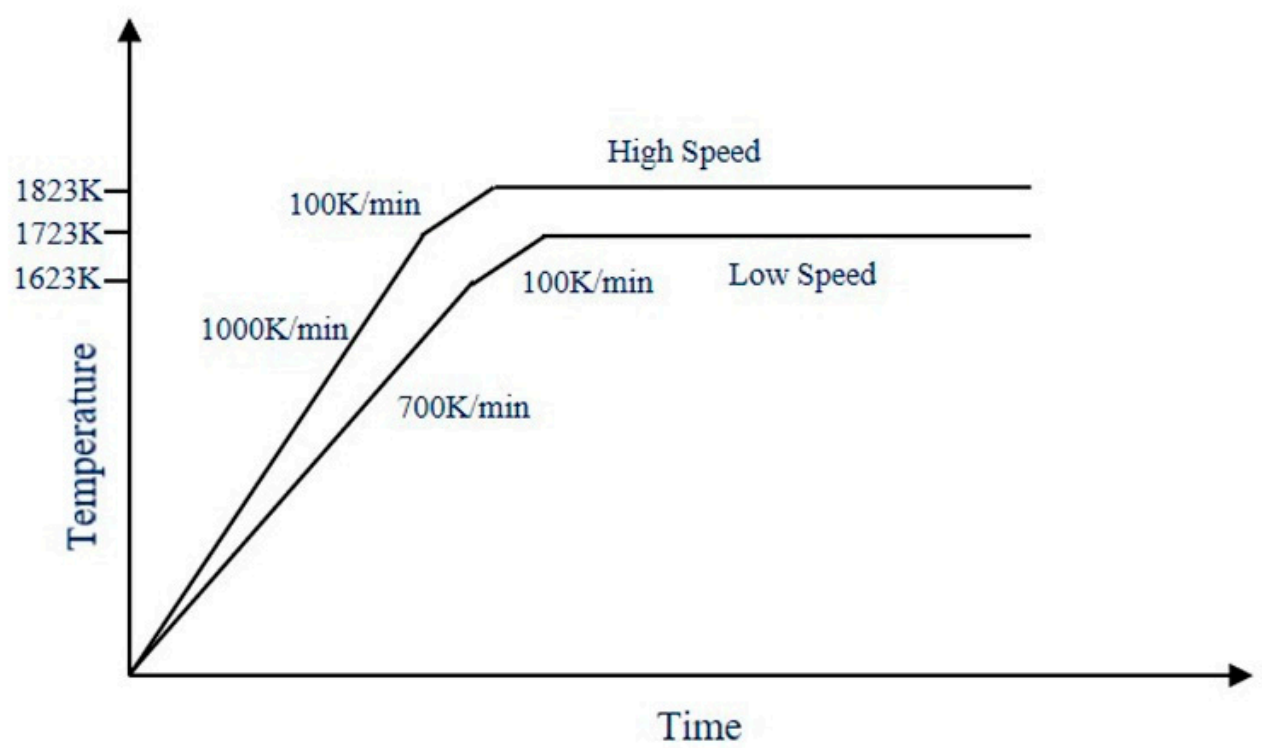

Figure 5. Thermal cycle curve of inclusions dissolution in slags for LSCM experiments.

\subsection{Steel-Slag Reaction in a High-Temperature Furnace}

A controlled atmosphere high temperature furnace was used for the steel-slag reaction in Figure 6; it is made by the Carbolite Gero company and its heating temperature can reach $1973 \mathrm{~K}\left(1700^{\circ} \mathrm{C}\right)$ under protective gas. About $170 \mathrm{~g}$ of steel sample (the composition is shown in Table 3) was placed in the corundum crucible, and the graphite crucible was sheathed. The premelted slag with $15 \mathrm{wt} \%$ of steel sample (based on the proportion of actual slag weight in molten steel) was put into the crucible, and the inert gas Ar with a flow rate of $20 \mathrm{~L} / \mathrm{h}$ was introduced. The composition of the slag sample was determined by previous experiments. The steel and slag were heated to $1823 \mathrm{~K}\left(1550{ }^{\circ} \mathrm{C}\right)$ and maintained for $90 \mathrm{~min}$, and then cooled rapidly to observe the modified inclusions in the steel and the interface reaction between the steel, slag, and refractory. The whole sample and crucible were split along the longitudinal axis, half of which was used to observe the change of the steel-slag interface, and the other half was used for metallographic observation and oxygen and nitrogen analysis. 


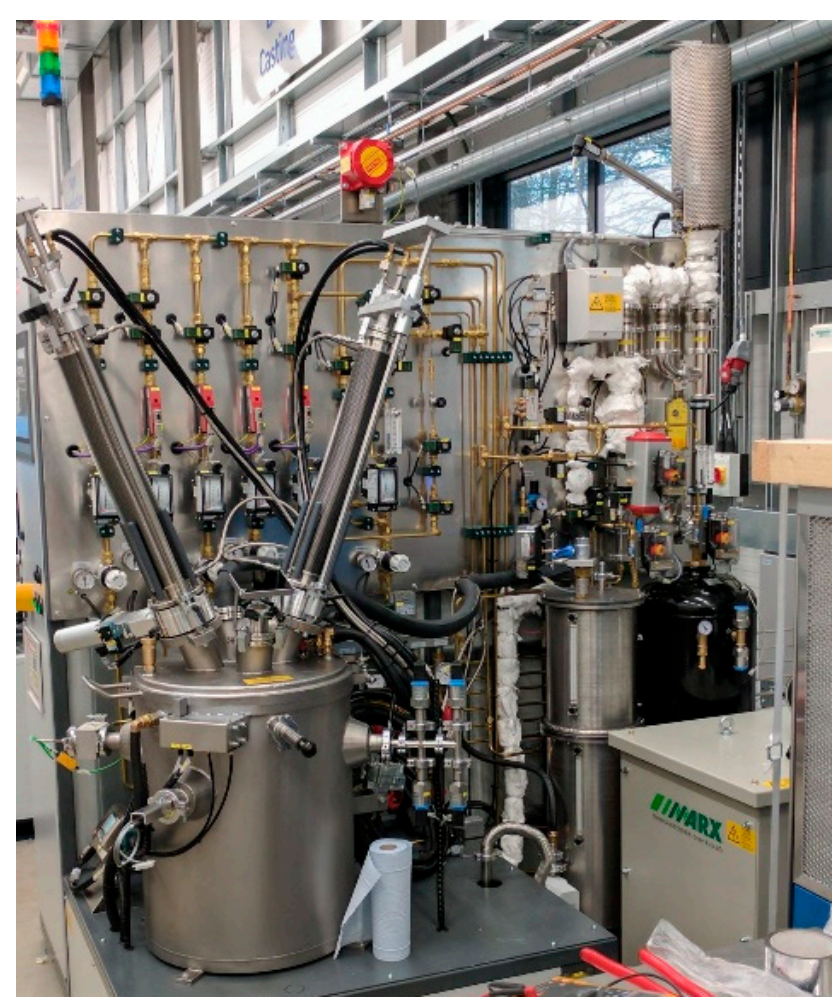

Figure 6. High temperature furnace for the steel-slag reaction.

Table 3. Compositions of the experimental steel ( $w t \%)$.

\begin{tabular}{ccccccccccc}
\hline $\begin{array}{c}\text { Low-Alloy } \\
\text { Model }\end{array}$ & Fe & C & Si & Mn & P & S & Cr & Al & Nb & Ti \\
\hline Average & 98.7 & 0.0385 & 0.00460 & 0.0105 & 0.000500 & 0.00290 & 0.00170 & 1.13 & 0.00110 & $<0.0005$ \\
\hline
\end{tabular}

\subsection{Sample Analysis}

The composition of high aluminum steel sample was analyzed using Foundry-Master Pro (FMP) made by Oxford, UK. The morphology and composition of the inclusions in the steel were analyzed using a Zeiss SIGMAFEG electron microscope and Oxford EDS. The dissolution behavior of the inclusions in the slag was observed with a VL2000DX high-temperature confocal microscope (the highest temperature was $1973 \mathrm{~K}\left(1700{ }^{\circ} \mathrm{C}\right)$, the maximum heating rate was $20 \mathrm{~K} / \mathrm{s}$, the maximum cooling rate was $100 \mathrm{~K} / \mathrm{s}$, and the maximum sample size was $8 \mathrm{~mm} \times 8 \mathrm{~mm} \times 4 \mathrm{~mm}$ ), and it is made by Lasertec Corporation, Yokohama, Japan. The slag samples after the high-temperature furnace test were analyzed by XRF. The reaction interface between the inclusions, slag, and refractory was also observed by SEM.

\section{Results Analysis of LSCM Experiment}

\subsection{Inclusion Aggregation Behavior}

Figure 7andFigure 8 demonstrate the aggregation growth behavior of $\mathrm{Al}_{2} \mathrm{O}_{3}$ inclusions. Figure 7 shows a series of high-temperature confocal scanning electron microscope continuous photographs, and Figure 8 corresponds to the aggregation state of inclusions in the solidified sample. It can be seen the inclusions gradually aggregate from a single particle smaller than $10 \mu \mathrm{m}$ to large inclusions of more than $50 \mu \mathrm{m}$. More than $90 \%$ of inclusions in steel belong to $\mathrm{Al}_{2} \mathrm{O}_{3}$. Because the LSCM equipment cannot analyze the inclusion compositions in the test process, the compositions of different inclusions are mainly 
dependent on EDS. In addition, the type of inclusions can be determined by referring to the morphological differences of different inclusions in the references [15-18].

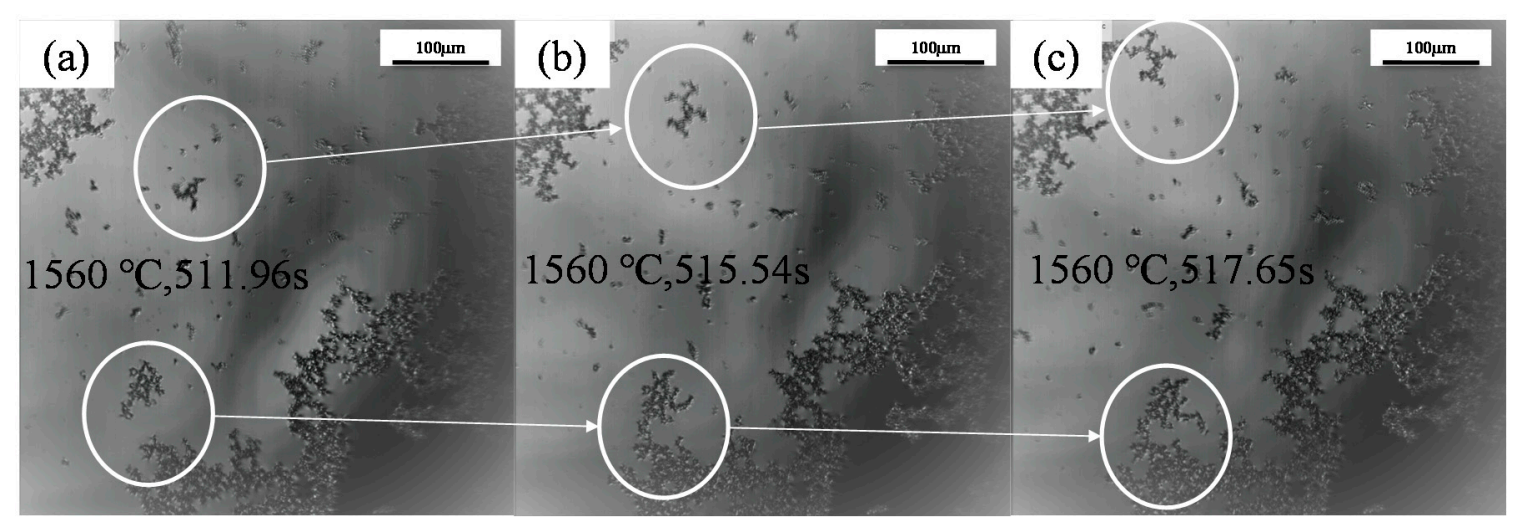

Figure 7. Sequences of the inclusion agglomeration behavior in the melting process of high Al steel: (a) $511.96 \mathrm{~s}$, (b) $515.54 \mathrm{~s}$, and (c) $517.65 \mathrm{~s}$.

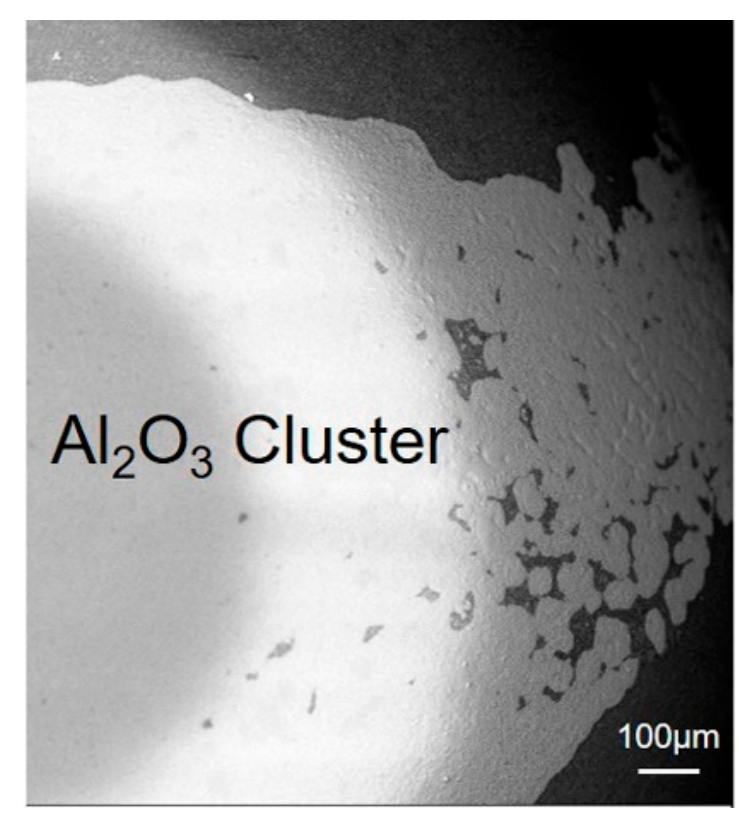

Figure 8. $\mathrm{Al}_{2} \mathrm{O}_{3}$ cluster on the steel surface at room temperature after inclusion floating.

It can be seen intuitively that the alumina inclusions are mainly dendritic, and the original alumina size is generally less than or equal to $10 \mu \mathrm{m}$. The collision and aggregation of inclusions in Figure 7 are generally about $2-3$ s. Moreover, the size of the polymerised inclusions is greater than $30 \mu \mathrm{m}$, and they will also be combined with larger cluster inclusions. The moving speed of the inclusions increases with the shortening of the distance between the two. Before reaching the final aggregation, it can be clearly seen that the attraction between large inclusions is stronger than that between small inclusions. Based on the LSCM experiment, the attraction values between different inclusions can be obtained by the calculation formula, referring to H. B. Yin [10,11]. Assuming that two identical alumina sheets are suspended in parallel, close to each other and partially immersed in the solution, the total attraction formula between the two inclusions can be deduced as follows:

$$
\begin{gathered}
F=0.5 g\left(\rho_{L}-\rho_{G}\right) w \Delta h^{2} \\
\Delta h=2 \gamma \cos \theta / g\left(\rho_{L}-\rho_{G}\right) \delta
\end{gathered}
$$


where $w$ is the width of plates; $g$ is the gravity acceleration; $\gamma$ is the liquid surface tension; $\theta$ is the contact angle between the liquid and solid plate; $\delta$ is the spacing between two parallel plates; and $\rho_{\mathrm{L}}$ and $\rho_{\mathrm{G}}$ are the densities of the liquid and gas phases $\left(\rho_{\mathrm{G}}\right.$ can be ignored here), respectively. Obviously, $\Delta h$ is proportional to $\delta^{-1}$, which determines the strength of the attraction.

If the separation between two inclusions is above $50 \mu \mathrm{m}$, the attraction $\mathrm{F}$ between them can be greater than $10^{-16} \mathrm{~N}$. The formation of cluster-like alumina inclusions by a collision can be promoted by the attraction between the inclusions, and eventually the loose cluster-like inclusions will become dense, and the attractive distance increases in series with an increase in the particle diameter.

\subsection{Dissolution of Inclusions in the Slag Phase}

Due to the high melting point and viscosity of slag 1, the residual bubbles in the slag have difficulty escaping quickly. In the melting process, it is easy to cause internal pores and surface foaming, which cannot complete the in-situ observation test of LSCM. The following content focuses on the analysis and discussion of the dissolution process of inclusions in slag 2 and slag 3. The detailing dissolution process of alumina in slag 2 and slag 3 are shown in Figure 9and Figure 10, respectively. Due to space limitation, the dissolution processes of other composite inclusions are no longer listed in this section, and the results are summarized in Table 4 .
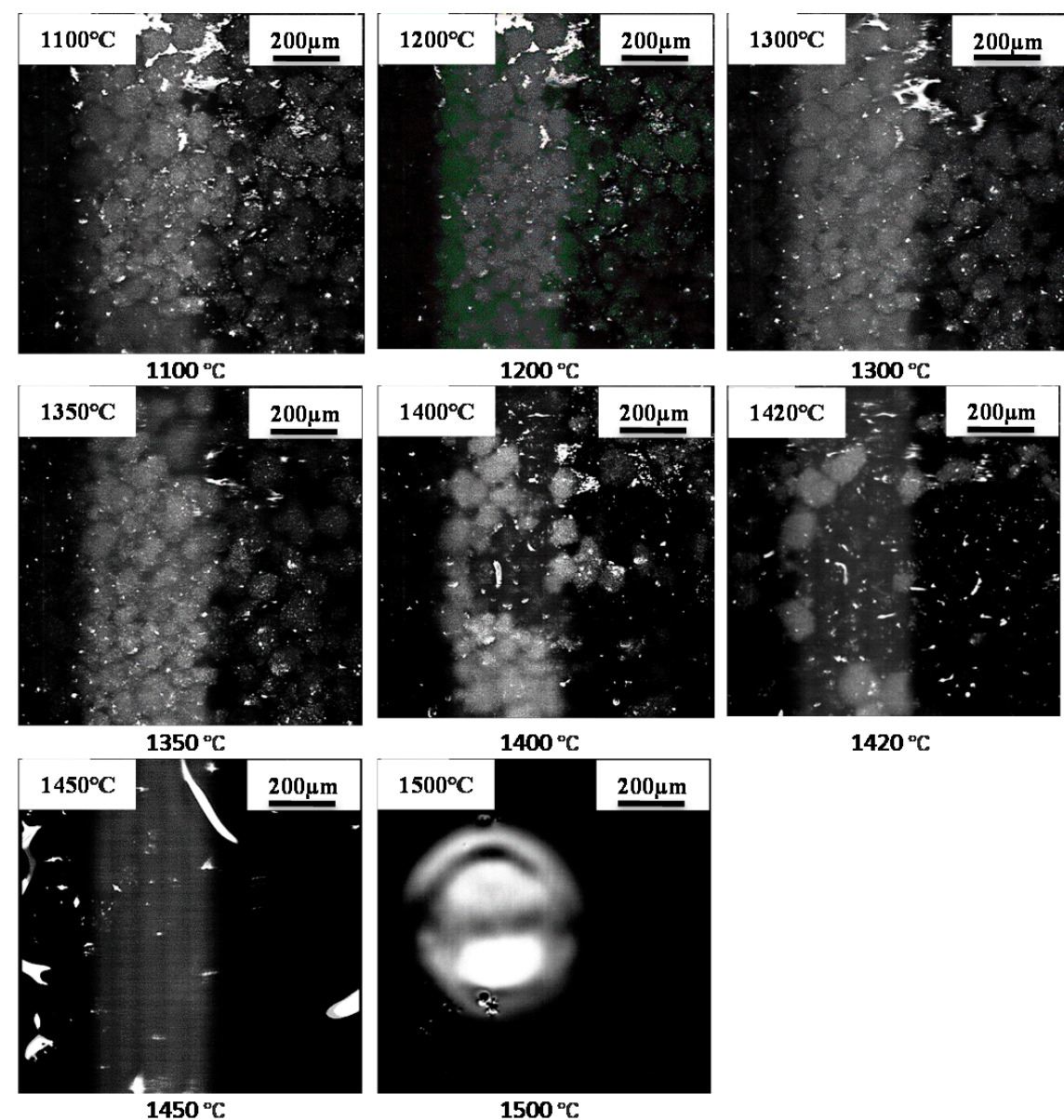

$1420^{\circ} \mathrm{C}$

Figure 9. Reaction behavior processes of $\mathrm{Al}_{2} \mathrm{O}_{3}$ in contact with slag 2 . 


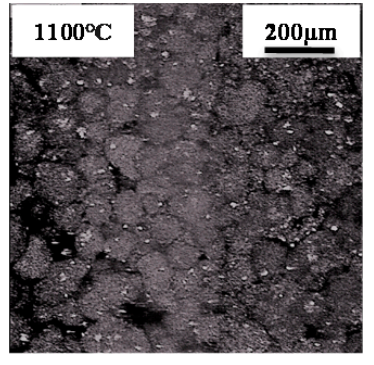

$1100^{\circ} \mathrm{C}$

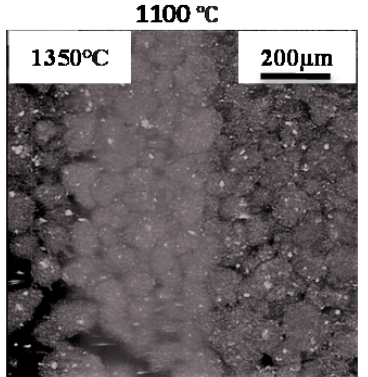

$1350^{\circ} \mathrm{C}$

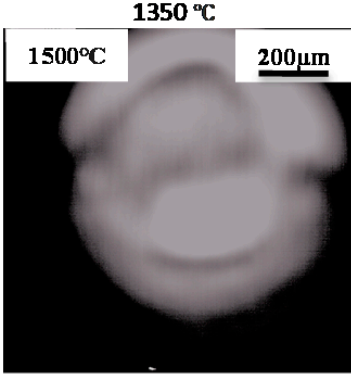

$1500^{\circ} \mathrm{C}$

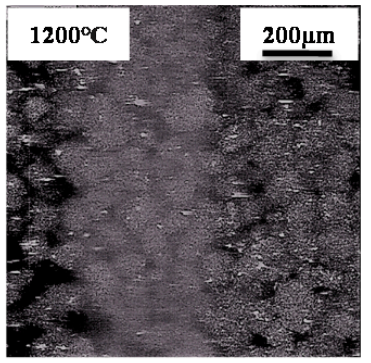

$1200^{\circ} \mathrm{C}$

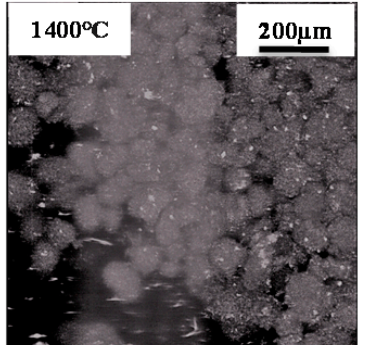

$1400^{\circ} \mathrm{C}$

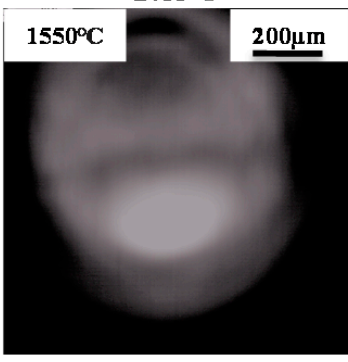

$15500^{\circ} \mathrm{C}$

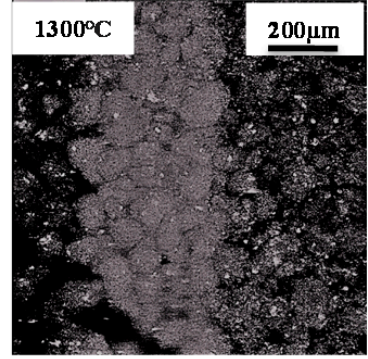

$1300^{\circ} \mathrm{C}$

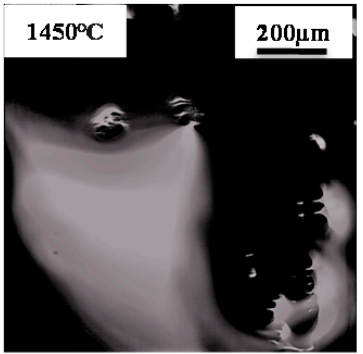

$1450^{\circ} \mathrm{C}$

Figure 10. Reaction behavior processes of $\mathrm{Al}_{2} \mathrm{O}_{3}$ in contact with slag 3 .

Table 4. Summary of inclusions dissolution reactions in the HT-LSCM.

\begin{tabular}{|c|c|c|c|c|c|}
\hline & & $\mathrm{Al}_{2} \mathrm{O}_{3}$ & $\mathrm{Al}_{2} \mathrm{O}_{3} \cdot \mathrm{TiN}$ & $\mathrm{MgO} \cdot \mathrm{Al}_{2} \mathrm{O}_{3}$ & $\mathrm{CaO} \cdot 2 \mathrm{Al}_{2} \mathrm{O}_{3}$ \\
\hline & Slag 1 & - & - & - & - \\
\hline \multirow[t]{3}{*}{ Reaction rate } & Slag 2 & $\uparrow \uparrow$ & $\uparrow$ & $\uparrow \uparrow \uparrow$ & $\uparrow \uparrow \uparrow$ \\
\hline & Slag 3 & $\uparrow \uparrow \uparrow$ & $\uparrow \uparrow \uparrow$ & $\uparrow \uparrow \uparrow$ & $\uparrow \uparrow \uparrow$ \\
\hline & Slag 1 & - & - & - & - \\
\hline \multirow[t]{2}{*}{ Reaction time } & Slag 2 & $70 \mathrm{~s}$ & $100 \mathrm{~s}$ & $30 \mathrm{~s}$ & $17 \mathrm{~s}$ \\
\hline & Slag 3 & $11 \mathrm{~s}$ & $12 \mathrm{~s}$ & $13 \mathrm{~s}$ & $11 \mathrm{~s}$ \\
\hline \multicolumn{2}{|c|}{ Reaction description } & Reduction & $\begin{array}{c}\text { Dissolution, } \\
\text { Precipitation of } \\
\mathrm{CaAl}_{2} \mathrm{O}_{4} \text { and } \\
\mathrm{Ca}_{3} \mathrm{Ti}_{2} \mathrm{O}_{6}\end{array}$ & Reduction & Reduction \\
\hline
\end{tabular}

$\uparrow$ means the speed of reaction rate.

By observing the dissolution condition of inclusions in slag 2, it can be seen that $\mathrm{MgO} \cdot \mathrm{Al}_{2} \mathrm{O}_{3}$ can be rapidly dissolved into the slag within $30 \mathrm{~s}$ when the heating temperature increases from $1523 \mathrm{~K}\left(1250{ }^{\circ} \mathrm{C}\right)$ to $1683 \mathrm{~K}\left(1410^{\circ} \mathrm{C}\right)$. When the heating temperature increases from $1523 \mathrm{~K}\left(1250{ }^{\circ} \mathrm{C}\right)$ to $1673 \mathrm{~K}\left(1410{ }^{\circ} \mathrm{C}\right), \mathrm{CaO} \cdot 2 \mathrm{Al}_{2} \mathrm{O}_{3}$ can be rapidly dissolved into the slag within $17 \mathrm{~s}$. As the heating temperature increases from $1623 \mathrm{~K}\left(1350{ }^{\circ} \mathrm{C}\right)$ to $1723 \mathrm{~K}$ $\left(1450{ }^{\circ} \mathrm{C}\right)$, the dissolution process of $\mathrm{Al}_{2} \mathrm{O}_{3} \cdot \mathrm{TiN}$ into slag takes about $100 \mathrm{~s}$. Under similar heating temperature conditions $\left(1350{ }^{\circ} \mathrm{C}\right.$ increased to $\left.1430{ }^{\circ} \mathrm{C}\right)$, it only took about $70 \mathrm{~s}$ for $\mathrm{Al}_{2} \mathrm{O}_{3}$ to dissolve into slag. According to the study of B.J. Monaghan, [19] the dissolution rate of the alumina inclusion in the liquid slag is mainly affected by the mass transfer of oxide in the liquid slag. The diffusion coefficient of the alumina inclusion at $1477-1577{ }^{\circ} \mathrm{C}$ is $10^{-11} \sim 10^{-10} \mathrm{~m}^{2} \mathrm{~s}^{-1}$. 
Therefore, the order of the dissolution time of inclusions in slag 2 was $\mathrm{CaO} \cdot 2 \mathrm{Al}_{2} \mathrm{O}_{3}<$ $\mathrm{MgO} \cdot \mathrm{Al}_{2} \mathrm{O}_{3}<\mathrm{Al}_{2} \mathrm{O}_{3}<\mathrm{Al}_{2} \mathrm{O}_{3} \cdot \mathrm{TiN}$. The order of final dissolution temperature was $\mathrm{Al}_{2} \mathrm{O}_{3} \cdot \mathrm{TiN}>$ $\mathrm{Al}_{2} \mathrm{O}_{3}>\mathrm{MgO} \cdot \mathrm{Al}_{2} \mathrm{O}_{3}>\mathrm{CaO} \cdot 2 \mathrm{Al}_{2} \mathrm{O}_{3}$. Among the above four inclusions, $\mathrm{Al}_{2} \mathrm{O}_{3} \cdot \mathrm{TiN}$ had the maximum dissolution temperature and dissolution time, which should be related to its overhigh melting point $\left(2930^{\circ} \mathrm{C}\right)$.

By observing the dissolution condition of the inclusions in slag 3, it can be concluded that $\mathrm{Al}_{2} \mathrm{O}_{3}$ can be quickly dissolved into the slag in $11 \mathrm{~s}$ when the heating temperature increases from $1573 \mathrm{~K}\left(1300{ }^{\circ} \mathrm{C}\right)$ to $1723 \mathrm{~K}\left(1450{ }^{\circ} \mathrm{C}\right)$. When the heating temperature increases from $1573 \mathrm{~K}\left(1300{ }^{\circ} \mathrm{C}\right)$ to $1723 \mathrm{~K}\left(1450{ }^{\circ} \mathrm{C}\right), \mathrm{Al}_{2} \mathrm{O}_{3} \cdot \mathrm{TiN}$ can be quickly dissolved into the slag within $12 \mathrm{~s}$. At the same heating temperature $\left(1300{ }^{\circ} \mathrm{C}\right.$ to $\left.1450{ }^{\circ} \mathrm{C}\right)$, the $\mathrm{CaO} \cdot 2 \mathrm{Al}_{2} \mathrm{O}_{3}$ dissolved in slag only needed about $11.15 \mathrm{~s}$. It took about $12.45 \mathrm{~s}$ for $\mathrm{MgO} \cdot \mathrm{Al}_{2} \mathrm{O}_{3}$ to dissolve into the slag as the heating temperature rose from $1623 \mathrm{~K}\left(1350{ }^{\circ} \mathrm{C}\right)$ to $1748 \mathrm{~K}\left(1475{ }^{\circ} \mathrm{C}\right)$. As in the above analysis, the dissolution time of $\mathrm{CaO} \cdot 2 \mathrm{Al}_{2} \mathrm{O}_{3}, \mathrm{MgO} \cdot \mathrm{Al}_{2} \mathrm{O}_{3}, \mathrm{Al}_{2} \mathrm{O}_{3}$, and $\mathrm{Al}_{2} \mathrm{O}_{3} \cdot \mathrm{TiN}$ inclusions was within $15 \mathrm{~s}$, and the dissolution rate was roughly the same. The reaction rate of the composite inclusions was very rapid, and they often dissolved into the slag before the slag was completely melted. Therefore, it is very important to select a suitable size and shape inclusions for testing.

The conclusions are summarized in Table 4 as follows. The composite oxides dissolve quickly in the slags; they only need a very short time and the dissolution time of the inclusions increases as their melting point increases. This indicates that the time length of the inclusion removal mainly depends on the floating process rather than the dissolution process.

\section{Results Analysis of Slag-Steel Reaction Experiment}

\subsection{Composition Changes of Slag and Molten Steel}

According to the high-temperature steel-slag reaction plan in Section 3.3, the slag and steel were separated and analyzed by XRF after the test. The slag composition obtained is shown in Table 5. In order to analyze the causes of change of each component, the reactivity between the component and [Al] can be judged by calculating the Gibbs free energy of the interface reaction between the slag component and dissolved [Al] in molten steel at a refining temperature. However, in actual reactions, the above reaction direction depends on the reaction constant resulting from the activity of individual reactant and product, which is a combination of the concentration and activity coefficient. It is assumed that the components in molten steel are in the standard state of $1 \%$ mass dilute solution, and the slag components are in the standard state of the pure substance. The reaction Equations (4)-(7) between the components in the slag and [Al] in the steel are as follows [20,21]:

$$
\begin{gathered}
3\left(\mathrm{SiO}_{2}\right)+4[\mathrm{Al}]=3[\mathrm{Si}]+2\left(\mathrm{Al}_{2} \mathrm{O}_{3}\right) \Delta \mathrm{G}^{\theta}=-668530+112.37 \mathrm{~T} \\
3(\mathrm{MgO})+2[\mathrm{Al}]=3[\mathrm{Mg}]+\left(\mathrm{Al}_{2} \mathrm{O}_{3}\right) \Delta \mathrm{G}^{\theta}=-993760+333.11 \mathrm{~T} \\
3(\mathrm{CaO})+2[\mathrm{Al}]=3[\mathrm{Ca}]+\left(\mathrm{Al}_{2} \mathrm{O}_{3}\right) \Delta \mathrm{G}^{\theta}=-733500-59.7 \mathrm{~T} \\
\left(\mathrm{~B}_{2} \mathrm{O}_{3}\right)+2[\mathrm{Al}]=2[\mathrm{~B}]+2\left(\mathrm{Al}_{2} \mathrm{O}_{3}\right) \Delta \mathrm{G}^{\theta}=-458280+125.92 \mathrm{~T}
\end{gathered}
$$

\begin{tabular}{|c|c|c|c|c|c|c|c|}
\hline Type & $\mathrm{CaO}$ & $\mathrm{Al}_{2} \mathrm{O}_{3}$ & $\mathrm{MgO}$ & $\mathrm{SiO}_{2}$ & $\mathrm{~B}_{2} \mathrm{O}_{3}$ & $\mathrm{Fe}_{2} \mathrm{O}_{3}$ & $\mathrm{MnO}$ \\
\hline Slag $1^{\mathrm{a}}$ & 29.8 & 64.1 & 5.12 & 0.58 & - & 0.12 & 0.010 \\
\hline Slag $2^{\mathrm{a}}$ & 28.1 & 63.9 & 7.39 & - & - & 0.32 & 0.002 \\
\hline Slag $3^{a}$ & 27.7 & 61.3 & 10.44 & - & - & 0.22 & 0.005 \\
\hline
\end{tabular}

Table 5. Weight changes of the slag compositions after reaction with high $\mathrm{Al}$ steel (wt\%).

${ }^{\mathrm{a}}$ Slag means the composition of slag after reaction.

The thermodynamic equilibrium calculation results of the slag and molten steel at $1873 \mathrm{~K}\left(1600{ }^{\circ} \mathrm{C}\right)$ are shown in Table 6 . Combined with the change of slag composition in Table 5, it can be seen that $\mathrm{SiO}_{2}$ and $\mathrm{B}_{2} \mathrm{O}_{3}$ were basically exhausted after the equilibrium 
reaction, which is consistent with the thermodynamic calculation results. A large number of $\mathrm{Al}_{2} \mathrm{O}_{3}$ inclusions were absorbed by the slag, which led to an increase in $\mathrm{Al}_{2} \mathrm{O}_{3}$ content. The oxidation ability of slag is very low, and $(\mathrm{FeO}+\mathrm{MnO})$ is not more than $0.322 \mathrm{wt} \%$. The $\mathrm{MgO}$ content in slag 3 increased, which may be related to the erosion of the lining refractory.

Table 6. Gibbs free energy of the chemical reactions between liquid steel and different slags $\left(\mathrm{J} \cdot \mathrm{mol}^{-1}\right)$.

\begin{tabular}{cccc}
\hline$\Delta \mathbf{G}, \mathbf{1 8 7 3} \mathbf{K}$ & Slag 1 & Slag 2 & Slag 3 \\
\hline $\mathrm{SiO}_{2}$ & $-411,277.16$ & $-425,145.13$ & - \\
$\mathrm{B}_{2} \mathrm{O}_{3}$ & $-250,216.69$ & $-237,176.30$ & $-234,726.58$ \\
$\mathrm{MgO}$ & $-19,835.69$ & $-13,848.84$ & $-15,368.97$ \\
$\mathrm{CaO}$ & $351,489.4$ & $391,461.65$ & $345,238.0$ \\
\hline
\end{tabular}

According to the composition change situations of molten steel in Table 7, [Si], [B], and [Ti] in the steel increased, and the [Al] content decreased sharply, which is consistent with the changing trend of the components in the slag. The Gibbs free energy of the reaction between $\mathrm{SiO}_{2}, \mathrm{~B}_{2} \mathrm{O}_{3}, \mathrm{MgO}$, and [Al] in molten steel had a very low negative value, indicating that the reaction ability between them should be strong, and the reactivity of $\mathrm{CaO}$ as relatively low in the reaction. The initial slag 1 and slag 2 included $5 \mathrm{wt} \% \mathrm{SiO}_{2}$, which would be reduced even if the content was small, because the $\Delta \mathrm{G}$ between [Al] and $\mathrm{SiO}_{2}$ was too small. During the slag-steel reaction, due to the crucible erosion and inclusions, the absorption increased the overall weight of the slag, resulting in a decrease in the relative content of $\mathrm{CaO}$. In addition, with the decrease of other components in the slag, the reaction trend between [Al] and $\mathrm{CaO} / \mathrm{MgO}$ in the high basicity slag was enhanced [22], and the $\mathrm{CaO}$ content in all of the slags decreased significantly.

Table 7. Compositions of high $\mathrm{Al}$ liquid steel after reactions with different slags (wt $\%)$.

\begin{tabular}{ccccccccccc}
\hline Sample & $\mathbf{C}$ & $\mathbf{S i}$ & $\mathbf{M n}$ & $\mathbf{P}$ & $\mathbf{S}$ & $\mathbf{C r}$ & $\mathbf{N i}$ & $\mathbf{A l}$ & $\mathbf{T i}$ & $\mathbf{B}$ \\
\hline Blank & 0.023 & 0.013 & 0.013 & 0.0005 & 0.0033 & 0.0057 & 0.0081 & 1.25 & 0.0019 & 0.0014 \\
Steel-1 & 0.052 & 0.263 & 0.015 & $<0.0005$ & 0.0066 & 0.0054 & 0.0067 & 0.577 & 0.0072 & 0.0288 \\
Steel-2 & 0.081 & 0.272 & 0.022 & 0.0005 & 0.0056 & 0.009 & 0.0087 & 0.569 & 0.0079 & 0.0276 \\
Steel-3 & 0.037 & 0.022 & 0.015 & 0.0006 & 0.0049 & 0.0033 & 0.0078 & 0.832 & 0.0058 & 0.0394 \\
\hline
\end{tabular}

\subsection{Changes of Inclusions in Steel}

From Figure 11, the inclusions were mainly $\mathrm{Al}_{2} \mathrm{O}_{3}$ or $\mathrm{Al}_{2} \mathrm{O}_{3}-(\mathrm{AlN})$ in the blank sample, with minimal spinel and calcium silicate aluminate. The collision time of the inclusions in the steel was less than $3 \mathrm{~s}$ and they floated up very fast according to the previous discussion. After the reaction of high $\mathrm{Al}$ liquid steel with different slags, the average total oxygen content of the three samples was below $5 \mathrm{ppm}$ according to the oxygen and nitrogen gas analysis, which shows that the number of inclusions in the steel was relatively less, and the residual inclusions types in other samples were as follows: (1) The types of inclusions are mainly $\leq 10 \mu \mathrm{m} \mathrm{SiO}{ }_{2}-\mathrm{Al}_{2} \mathrm{O}_{3}$ and a small amount of $\mathrm{MgO}_{-} \mathrm{Al}_{2} \mathrm{O}_{3}$ in steel-1. (2) The typical inclusions changed from $\mathrm{Al}_{2} \mathrm{O}_{3}$ into $\leq 5 \mu \mathrm{m} \mathrm{MgO}-\mathrm{Al}_{2} \mathrm{O}_{3}-(\mathrm{AlN})$ and $\mathrm{SiO}_{2}-\mathrm{Al}_{2} \mathrm{O}_{3}$ in steel-2. (3) The typical inclusions finally changed into $\leq 5 \mu \mathrm{m} \mathrm{CaO}-\mathrm{MgO}-\mathrm{Al}_{2} \mathrm{O}_{3}$ and $\mathrm{MgO}-\mathrm{Al}_{2} \mathrm{O}_{3}-(\mathrm{CaS})$ in steel-3. 


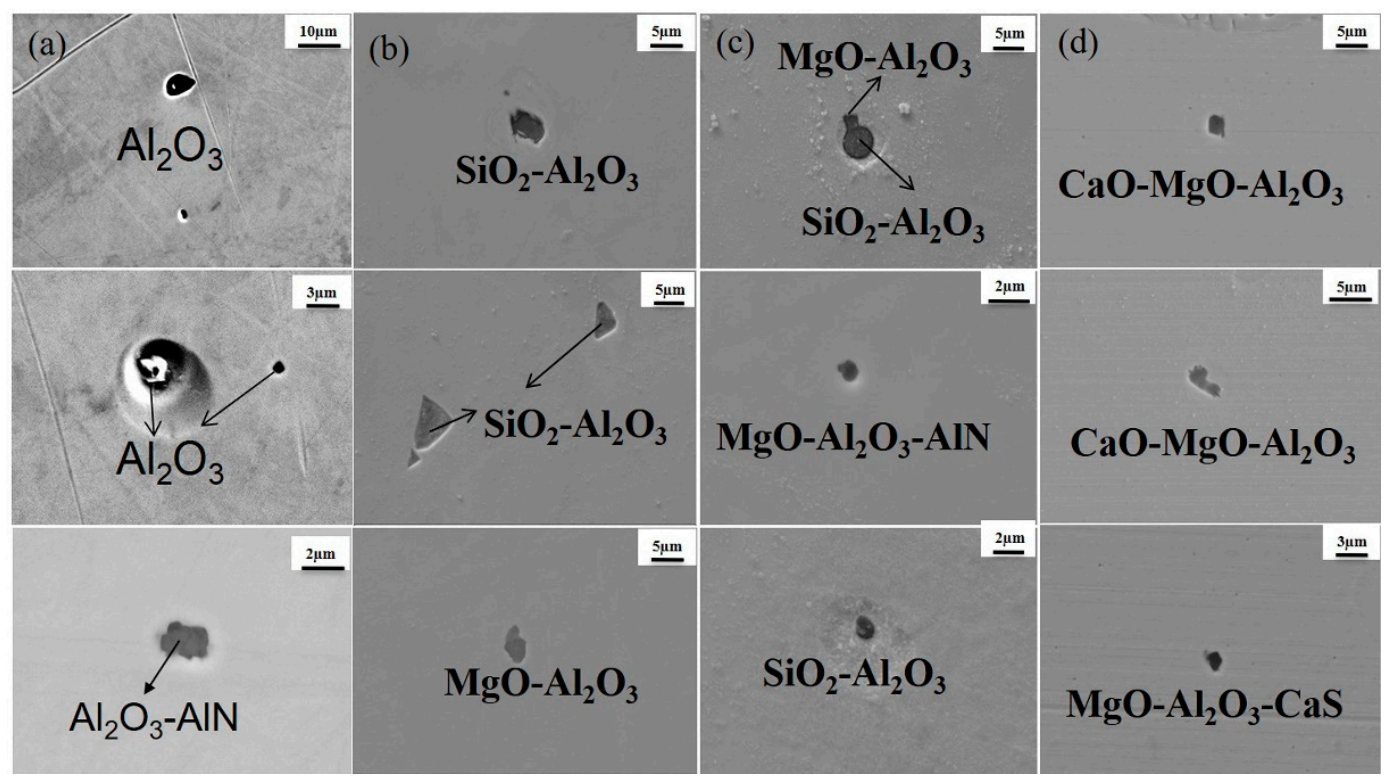

Figure 11. Changes of inclusion types after high $\mathrm{Al}$ steel reacted with different slags in the experiment: (a) blank sample, (b) steel-1 (slag1), (c) steel-2 (slag2), and (d) steel-3 (slag3).

The reasons for inclusion formation are as follows: according to the calculation results in Table 6, the [Al] in steel can easily react with $\mathrm{SiO}_{2}$ in slag 1 and slag 2, resulting in an increase in the [Si] content in molten steel, and $\mathrm{SiO}_{2}-\mathrm{Al}_{2} \mathrm{O}_{3}$ binary inclusions would be formed first. $\mathrm{MgO}-\mathrm{Al}_{2} \mathrm{O}_{3}$ inclusions can be generated by lining erosion generally. In addition, $\mathrm{MgO}$ component is contained in all three slags, because Gibbs free energy of the reaction between molten steel and furnace slag was negative at $1873 \mathrm{~K}\left(1600{ }^{\circ} \mathrm{C}\right)$ in slag 3, and $\mathrm{MgO}$ is be reduced to $[\mathrm{Mg}]$ to form spinel, and $\mathrm{MgO}-\mathrm{Al}_{2} \mathrm{O}_{3}$ inclusions can be found in steel samples. Therefore, it is difficult to avoid the formation of the $\mathrm{MgO}-\mathrm{Al}_{2} \mathrm{O}_{3}$ spinel in the actual reaction process. Although slag 3 did not contain $\mathrm{SiO}_{2}$, the $\mathrm{CaO}$ content was still high and it could be reduced by [Al], resulting in $\mathrm{MgO}-\mathrm{Al}_{2} \mathrm{O}_{3}$ inclusions that could be modified to $\mathrm{CaO}-\mathrm{MgO}-\mathrm{Al}_{2} \mathrm{O}_{3}$ ternary inclusions when dissolved [Ca] enters steel-3.

In summary, the content of $\mathrm{Al}_{2} \mathrm{O}_{3}$ increases with the reaction between the slag composition and liquid steel. If the top slag cannot dissolve the accumulated $\mathrm{Al}_{2} \mathrm{O}_{3}$ at the slag-steel interface in time, $\mathrm{Al}_{2} \mathrm{O}_{3}$ inclusions will enter the liquid slag, which will destroy the uniformity and flow stability of the liquid slag. At the same time, the accumulated solid inclusions may also be trapped into the solidified shell during casting, resulting in quality problems such as slab surface defects and subsurface inclusions. Some research works [23-25] have been carried out for the dissolution of $\mathrm{Al}_{2} \mathrm{O}_{3}$ in slag, demonstrating that the dissolution rate of $\mathrm{Al}_{2} \mathrm{O}_{3}$ decreased with increasing the $\mathrm{Al}_{2} \mathrm{O}_{3}$ content in the slag, and because the driving force of the inclusion dissolution decreased, the boundary layer diffusion inside the slag phase was the rate limiting step of the dissolution process. Furthermore, the addition of small amounts of $\mathrm{SiO}_{2}$ could result in a significant decrease in the dissolution rate, and because of this, the slag viscosity increased so as to decrease diffusion coefficient, while $\mathrm{MgO}$ could lead to the opposite result. In order to reduce the slag-steel reaction and improve the inclusion dissolution ability, the $\mathrm{SiO}_{2}$ content in the slag components should be as low as possible, so the performance of slag 3 was better than the other two slags, and $\mathrm{Al}_{2} \mathrm{O}_{3}$ or $\mathrm{SiO}_{2}-\mathrm{Al}_{2} \mathrm{O}_{3}$ inclusions could be changed into $\leq 5 \mu \mathrm{m}$ $\mathrm{CaO}-\mathrm{MgO}-\mathrm{Al}_{2} \mathrm{O}_{3}$ and $\mathrm{MgO}-\mathrm{Al}_{2} \mathrm{O}_{3}-(\mathrm{CaS})$ in high $\mathrm{Al}$ steel.

\section{Conclusions}

We focused on the behavior of $\mathrm{Al}_{2} \mathrm{O}_{3}, \mathrm{Al}_{2} \mathrm{O}_{3} \cdot \mathrm{TiN}, \mathrm{Al}_{2} \mathrm{O}_{3} \cdot \mathrm{MgO}$, and $\mathrm{CaO} \cdot 2 \mathrm{Al}_{2} \mathrm{O}_{3}$ inclusions in high $\mathrm{Al}$ steel in contact with three different slag compositions in this study. The real-time dynamic process of various behaviors of small solid inclusion particles 
on molten steel and slag surface has been successfully observed by using LSCM, and the important phenomena of the collision, agglomeration, and dissolution from different particles are investigated. The main results can be summarized as follows:

(1) According to the thermodynamic calculations, the absorption of different inclusions has little effect on the composition of refining slag, which is less than $2 \mathrm{wt}-\%$. The experimental results of the high-temperature experiment are consistent for the interaction calculations at the steel-slag interface. This showed that the slag composition is greatly influenced by the slag-steel-refractory reaction.

(2) The order of dissolution time of inclusions in slag 2 is $\mathrm{CaO} \cdot 2 \mathrm{Al}_{2} \mathrm{O}_{3}<\mathrm{MgO} \cdot \mathrm{Al}_{2} \mathrm{O}_{3}<$ $\mathrm{Al}_{2} \mathrm{O}_{3}<\mathrm{Al}_{2} \mathrm{O}_{3} \cdot \mathrm{TiN}$. The order of the final dissolution temperature is $\mathrm{Al}_{2} \mathrm{O}_{3} \cdot \mathrm{TiN}>$ $\mathrm{Al}_{2} \mathrm{O}_{3}>\mathrm{MgO} \cdot \mathrm{Al}_{2} \mathrm{O}_{3}>\mathrm{CaO} \cdot 2 \mathrm{Al}_{2} \mathrm{O}_{3}$, and the dissolution time of inclusions increases as their melting point increasing. Compared with slag 2, the composite oxides dissolve faster in slag 3, and the dissolution time of four inclusions only takes less than $15 \mathrm{~s}$ and the dissolution rate is basically the same.

(3) In order to reduce the slag-steel reaction and improve the inclusion morphology and size, the suitable slag composition should be $\mathrm{CaO} / \mathrm{Al}_{2} \mathrm{O}_{3}=1.4, \mathrm{MgO}=6 \mathrm{wt}-\%$, and $\mathrm{B}_{2} \mathrm{O}_{3}=3 \mathrm{wt}-\% . \quad \mathrm{Al}_{2} \mathrm{O}_{3}$ or $\mathrm{SiO}_{2}-\mathrm{Al}_{2} \mathrm{O}_{3}$ inclusions can be changed into $\leq 5 \mu \mathrm{m}$ $\mathrm{CaO}-\mathrm{MgO}-\mathrm{Al}_{2} \mathrm{O}_{3}$ and $\mathrm{MgO}-\mathrm{Al}_{2} \mathrm{O}_{3}-(\mathrm{CaS})$ in high $\mathrm{Al}$ steel.

Author Contributions: Methodology, S.Z. and Z.L.; Investigation, R.X. and D.K.; Validation, G.S.; Writing-original draft preparation, S.Z.; Writing—review and editing, S.Z.; Supervision, Z.L.; Funding acquisition, S.Z. and D.X. All authors have read and agreed to the published version of the manuscript.

Funding: This work was supported by National Natural Science Foundation of China (under grant 51904086, 51904085), the Returned Overseas Scholars Foundation of Hebei Province (C20200310 and C201806), the Iron and Steel Joint Foundation of Hebei Province (E2020402016), the Science and Technology Special Program of Handan City (19422111008-33), and the Advanced Manufacturing and Materials Centre, University of Warwick.

Data Availability Statement: Not applicated.

Conflicts of Interest: The authors declare no conflict of interest.

\section{References}

1. Xu, J.F.; Wang, K.P.; Wang, Y.; Qu, Z.D.; Tu, X.K. Effects of ferrosilicon alloy, Si content of steel, and slag basicity on compositions of inclusions during ladle furnace refining of Al-killed steel. J. Iron Steel Res. Int. 2020, 27, 1011-1017. [CrossRef]

2. Wang, G.C.; Zhao, Y.; Xiao, Y.Y.; Jin, P.L.; Li, S.L.; Sridhar, S. Diversified aggregated patterns of alumina inclusions in high-Al iron melt. Met. Mater. Trans. A 2020, 51, 3051-3066. [CrossRef]

3. Yang, J.; Chen, D.F.; Zhu, M.Y. Crystallization and heat transfer of $\mathrm{CaO}-\mathrm{SiO}_{2}$-based slag for high-Mn-high-Al steel. J. Iron Steel Res. Int. 2020, 27, 788-795. [CrossRef]

4. Chen, G.J.; He, S.P.; Wang, Q. Dissolution behavior of $\mathrm{Al}_{2} \mathrm{O}_{3}$ into tundish slag for high-Al steel. J. Mater. Res. Technol. 2020, 9, 11311-11318. [CrossRef]

5. Dewangan, S.; Behera, S.; Chowrasia, M.K. Comparative analysis into mechanical properties and microstructural attributes of quenched and tempered 0.2\%-C steel. World J. Eng. 2020, 17, 127-133. [CrossRef]

6. He, S.P.; Chen, G.J.; Guo, Y.T.; Shen, B.Y.; Wang, Q. Morphology control for $\mathrm{Al}_{2} \mathrm{O}_{3}$ inclusions without Ca treatment in highaluminum steel. Met. Mater. Trans. B 2015, 46, 585-594. [CrossRef]

7. Zhao, K.W.; He, S.P.; Zeng, J.H.; Wang, Q.; Wang, X.H. Study on key technology of 38CrMoAl steel produced by BOF-LF-RH-CC process. Iron Steel 2009, 44, 38-41.

8. Wang, R. Metallurgical technology and defects control of cold rolled sheet IF Steel. Ph.D. Thesis, Beijing University of Science and Technology, Beijing, China, 2017.

9. Monaghan, B.J.; Chen, L. Effect of changing slag composition on spinel inclusion dissolution. Ironmak. Steelmak. 2006, 33, 323-330. [CrossRef]

10. Shibata, H.; Yin, H.B.; Yoshinaga, S.; Emi, T.; Suzuki, M. In-situ observation of engulfment and pushing of nonmetallic inclusions in steel melt by advancing melt/solid interface. ISIJ Int. 1998, 38, 149-156. [CrossRef]

11. Yin, H.B.; Shibata, H.; Emi, T.; Suzuki, M. In-situ observation of collision, agglomeration and cluster formation of alumina inclusion particles on steel melts. ISIJ Int. 1997, 37, 936-945. [CrossRef] 
12. Xuan, C.J.; Mu, W.Z.; Olano, Z.I.; Jonsson, P.G.; Nakajima, K. Effect of the Ti, Al contents on the inclusion characteristics in steels with $\mathrm{TiO}_{2}$ and TiN particle additions. Steel Res. Int. 2016, 87, 911-920. [CrossRef]

13. Michelic, S.K. Experimental study on the behavior of $\mathrm{TiN}$ and $\mathrm{Ti}_{2} \mathrm{O}_{3}$ inclusions in contact with $\mathrm{CaO}-\mathrm{Al}_{2} \mathrm{O}_{3}-\mathrm{SiO}_{2}-\mathrm{MgO}$ slags Scanning 2017, 4, 1-14. [CrossRef] [PubMed]

14. Liu, W.; Yang, S.F.; Li, J.S.; Wang, F.; Yang, H.B. Numerical model of inclusion separation from liquid metal with consideration of dissolution in slag. J. Iron Steel Res. Int. 2019, 26, 1147-1153. [CrossRef]

15. Mu, W.Z.; Dogan, N.; Coley, K.S. Agglomeration of non-metallic inclusions at the steel/Ar interface: Model application. Met. Mat. Trans. B 2017, 48, 2092-2103. [CrossRef]

16. Mu, W.Z.; Dogan, N.; Coley, K.S. Agglomeration of non-metallic inclusions at steel/Ar interface: In-situ observation experiments and model validation. Met. Mat. Trans. B 2017, 48, 2379-2388. [CrossRef]

17. Zhang, P.C. Deoxidation and slagging in High Al steel. Master's Thesis, Northeastern University, Shenyang, China, 2011.

18. Sridhar, S.; Cramb, A.W. Kinetics of $\mathrm{Al}_{2} \mathrm{O}_{3}$ dissolution in $\mathrm{CaO}-\mathrm{MgO}-\mathrm{SiO}_{2}-\mathrm{Al}_{2} \mathrm{O}_{3}$ slags: In situ observations and analysis. Met. Mat. Trans. B 2000, 31, 406-410. [CrossRef]

19. Monaghan, B.J.; Chen, L. Dissolution behavior of alumina micro-particles in $\mathrm{CaO}-\mathrm{SiO}_{2}-\mathrm{Al}_{2} \mathrm{O}_{3}$ liquid oxide. J. Non-Cryst. Solids 2004, 347, 254-261. [CrossRef]

20. Liang, Y.J.; Che, Y.C. Thermodynamic Data Book of Inorganic Materials; Northeastern University Press: Shenyang, China, 1993.

21. Huang, X.H. Principle of Iron and Steel, 3rd ed.; Metallurgy Industry Press: Beijing, China, 2008.

22. Jiang, M.; Wang, X.H.; Chen, B.; Wang, W.J. Laboratory study on evolution mechanisms of non-metallic inclusions in high strength alloyed steel refined by high basicity slag. ISIJ Int. 2010, 50, 95-104. [CrossRef]

23. Tse, C.; Lee, S.H.; Sridhar, S.; Cramb, A.W. In Proceedings of the 83th Steelmaking Conference, Pittsburgh, PA, USA, 26-29 March 2000; Iron and Steel Society: Warrendale, PA, USA, 2000; pp. 219-229.

24. Cho, W.D.; Fan, P. Diffusional dissolution of alumina in various steelmaking slags. ISIJ Int. 2004, 44, 229-234. [CrossRef]

25. Choi, J.Y.; Lee, H.G.; Kim, J.S. Dissolution rate of $\mathrm{Al}_{2} \mathrm{O}_{3}$ into molten CaO-SiO${ }_{2}-\mathrm{Al}_{2} \mathrm{O}_{3}$ slags. ISIJ Int. 2002, 42, 852-860. [CrossRef] 